\title{
Challenges Facing the Horticultural Sector in Nairobi County, Kenya
}

\author{
Miriam N. Muthoka ${ }^{1 *}$, Martin Ogutu ${ }^{2}$ \\ ${ }^{I}$ Doctoral Student, School of Business, Jomo Kenyatta University of Agriculture and Technology, PO Box \\ 29649-00100, Nairobi \\ ${ }^{2}$ Associate Professor, School of Business, University of Nairobi, PO Box 30197-00100, Nairobi
}

\begin{abstract}
The horticultural sector contributes significantly to the economic development of many countries including Kenya. However, the sector faces numerous challenges that hinder its full contribution to most economies especially in the developing countries. This study was carried out to determine the key challenges facing the horticultural sector in Nairobi County, Kenya. The study made use of primary data, collected from the management and staff of thirty six horticultural fims in the County.The data was analysed using frequencies and measures of central tendcency such as mean, mode and standard deviation. The study established that horticultural export firms faced several challenges in their operations which hinder their effective performance in the sector. The key challenges include rivalry within the industry, competition for source of suppliers, competition for warehousing facilities, competition for channels of distribution, lack of departments for strategy implementation, threat of new entrants to the market, market dominance by strong competitors, unique products by the competitors, price wars within the industry, competitors' wider branch network and lack of distribution networks. It is recommended that the management should device appropriate response strategies to address these challenges to ensure sustainable development of the horticultural sector in the County.
\end{abstract}

Key words: challenges, horticulture, Nairobi, Kenya

\section{Introduction}

Horticulture sector in Kenya has grown in the last decade to become the second largest earner of foreign exchange, employer and contributor to food needs in the country. Currently the horticulture industry is the fastest growing agricultural sub sector. Kenya's ideal tropical and temperate climatic condition makes it favorable for production of wide range of fruits, vegetables and flowers. Kenya is now by far the largest exporter of vegetables to the European Union (Dolan and Humphrey, 2000).

The global horticulture industry is being fuelled by increasing consumer demand for high quality products along with soaring seed demand to cater for a rapidly expanding global population. Consumers are demanding quality for money, especially when it comes to flowers. Commonly used for day-to-day home decoration in the past, flowers are playing an increasingly important role in the occasion's sector, with increasing numbers of consumers opting to give flowers to mark celebrations such as anniversaries or retirement parties. This is fueling demand for horticulture industries to adjust accordingly due to challenges that come with increased demand and quality checks for them to compete effectively.

Kenya is currently ranked the largest supplier of cut flowers to the European Union. It is the second largest developing-country exporter of flowers in the world after Colombia. It is the second largest horticultural exporter in sub-Saharan Africa after South Africa and the second largest developing country supplier of vegetables to the European Union after Morocco (Export Processing Zones Authority, 2005). Leguminous and 'Asian' vegetables have increasingly replaced coffee and tea as the major export crops. Horticultural produce (which includes vegetables, flowers and fruit) represents $13 \%$ of the value of Kenya's exports and is one of the top four foreign exchange earning industries (Chweya \& Kimenye 1995). Since 1995 the volume and value of horticultural exports has continued to grow reaching Ksh 14.9 million in 1998 (GoK, 2000).

\section{Literature review}

As Pearce and Robinson (2000) noted, an environment can be divided into two main subsets: Internal and external environment. They argued that the internal environment comprises factors such as the organizations competitive capabilities and both tangible and intangible resources that affect the firm's ability to meet its objectives. As Porter (1979) noted, it is prudent for any firm to understand the underlying sources of competitive pressure in their industry in order to formulate appropriate strategies to respond. Firms often respond to such environmental changes through strategic responses. Organizations have to cope with pressure of globalization, rapid changes in technology, rise of e-commerce, situations where customers and suppliers can be both competitors and allies and a change in emphasis from quantity to quality and from product to services. 
The firm's competitive environment is its immediate environment. Firms are dependent on the environment for survival in terms of resources and profitable market opportunities for their products in order to deal with competition. This therefore makes its important for firms to scan their environment in order to spot the trends and conditions that could affect the industry and adapt to them (Thomson and Stickland, 1993) and also identify if there are factors in the environment which influence the capability of an organization to position itself and gain competitive advantage (Johnson and Scholes, 1999). The firm's external environment includes three interrelated factors which determine the nature of opportunities, threats and constraints it faces. The remote environment has factors originating beyond the firm's operating situation- Economic, Social, Technological and Ecological (Pearce and Robinson, 2003). Considering that performance is the major objective of an organization, it is generally accepted that the structure and decision making in an organization is influenced by environmental complexity and volatility (Miles and Snow 1987).

\section{Study sample}

\section{Data and Methodology}

The targeted population for this study was all horticultural firms in Nairobi County of Kenya. There are thirty six (36) firms majorly export oriented. The firms are regulated by government and private agencies for smooth operations. These firms constituted the population of the study. This study made use of primary data. The primary data was obtained through data collected using semi structured questionnaire rated on Likert scale. The questionnaire had two major sections. The first section comprised general information, the second brought out the challenges faced by horticultural export firms, and the target respondents included the management staff in the horticultural firms, the strategic managers, or marketing managers. The questionnaires were administered through "drop and pick" method to respondents of the study.

\section{Data analysis}

The data collected was subjected to identification of errors with an aim of excluding them from the analysis report. The data was coded and analyzed through SPSS and using descriptive statistics which was used to give the frequencies of responses. Mean and standard deviation were also used. The analyzed data is presented in form of tables and charts for easy understanding and interpretation where the results have been used to draw conclusion on dependent and independent variables on how the Horticultural export firms are responding to challenges of competition.

\section{Results and Discussion}

\section{General information of the Firms}

Table 1: Duration of Firm operation in Kenya

\begin{tabular}{|l|l|l|}
\hline Period of Operation & Frequency & Percentage \\
\hline $5-10$ years & 2 & 12.5 \\
$10-15$ years & 5 & 31.3 \\
$15-20$ years & 6 & 37.5 \\
$20-25$ years & 1 & 6.2 \\
$25-30$ years & 2 & 12.5 \\
Total & $\mathbf{1 6}$ & $\mathbf{1 0 0 . 0}$ \\
\hline
\end{tabular}

The results in Table 1 indicate that most (37.5) of the horticultural firms in Kenya have operated in Kenya for a period of between 15-20 years, then followed by (31.3\%) of the firms which have operated between $10-15$ years, while very few of the firms $(6.2 \%)$ of them have been in existence for a period of between $20-25$ years. From the study findings on existence of branches in Table 2 most of the horticultural firms under study (64.7\%) have branches operating in the country while (35.5\%) of the firms have no branches in the country.

Table 2: Existence of branches of the company

\begin{tabular}{|ll|l|l|}
\hline Possession of $\quad$ branches & Frequency & Percent \\
\hline & Had branches & 11 & 64.7 \\
& No branches & 6 & 35.3 \\
& Total & $\mathbf{1 7}$ & $\mathbf{1 0 0 . 0}$ \\
& & & \\
\hline
\end{tabular}


Table 3: Comparison of performance of the branches

\begin{tabular}{|cl|l|l|}
\hline Performance of & branches & Frequency & Percent \\
\hline good & 10 & 83.3 \\
& excellent & 2 & 16.7 \\
& Total & $\mathbf{1 2}$ & $\mathbf{1 0 0 . 0}$ \\
& & \\
\hline
\end{tabular}

In comparison of the performance of the branches of the horticultural firms under study, the results in table above indicate that the performance of the branches in the country was good $(83.3 \%)$ as compared to $(16.7 \%)$ which was excellent performance.

Table 4: Firms and Operation in other parts of the world other than Kenya

\begin{tabular}{|ll|l|l|}
\hline Operation of firms & outside Kenya & Frequency & Percent \\
\hline Operation outside Kenya & 2 & 12.5 \\
No operation outside Kenya & 14 & 87.5 \\
Total & $\mathbf{1 6}$ & $\mathbf{1 0 0 . 0}$ \\
& & \\
\hline
\end{tabular}

The results indicate that most of the horticultural firms under study $(87.5 \%)$ do not operate in other parts of the world, while (12.5\%) of the firms have operations in other parts of the world apart from Kenya. As indicated in Table above, the majority of the horticultural firms in Nairobi County, Kenya under this study, (94.1\%) do not have a strategy implementation department in their organization while only (5.9\%) of the firms have a strategy implementation department within their organization.

Table 5 Existence of strategy implementation department

\begin{tabular}{|l|l|l|l|}
\hline Existence of & Department & Frequency & Percent \\
\hline \multirow{4}{*}{} & Department & 1 & 5.9 \\
\cline { 2 - 4 } & No Department & 16 & 94.1 \\
\cline { 2 - 4 } & Total & $\mathbf{1 7}$ & $\mathbf{1 0 0 . 0}$ \\
\hline
\end{tabular}

\section{Key challenges}

The key challenges facing horticultural firms in the County are summarised in Table 6 . The challenges were established by asking the respondents to give feedback on a scale of $1-5$ where $1=$ not at all; $2=$ little extent; $3=$ moderate extent; $4=$ great extent; $5=$ very great extent. The findings have been presented in the Table 6 and their interpretation given thereof.

Table 6: Challenges

\begin{tabular}{|l|l|l|}
\hline \multicolumn{1}{|c|}{ Competition Challenges } & Mean & Standard deviation \\
\hline Quality packaging by competitors & 2.59 & 1.121 \\
\hline Competition for transport challenges & 2.59 & 1.064 \\
\hline Quality standard of products & 2.71 & 1.047 \\
\hline Threat of new entrants to the market & 2.47 & .943 \\
\hline Market dominance by strong competitors & 2.94 & 1.478 \\
\hline Unique products by the competitors & 2.71 & 1.105 \\
\hline Rivalry within the industry & 3.18 & .883 \\
\hline Price wars within the industry & 1.111 \\
\hline Competition for source of suppliers & 2.88 & 1.185 \\
\hline Imitation by competitors & 3.18 & 1.144 \\
\hline Competitors wider branch network & 1.328 \\
\hline Competition for customers or markets & 2.06 & 1.115 \\
\hline Lack of distribution networks & 2.47 & 1.480 \\
\hline Competition for warehousing facilities & 2.65 & 1.458 \\
\hline Competition for channels of distribution & 2.76 & 1.468 \\
\hline Poaching of qualified staff & 3.00 & 1.522 \\
\hline Grand mean & 3.18 & $\mathbf{1 . 2 2}$ \\
\hline
\end{tabular}

The study sought to establish the competition challenges in the horticultural firms in Nairobi County, Kenya. From the results illustrated in the table 5 above, it is clear that there are four distinct competition challenges in the horticultural export firms. These include rivalry within the industry, competition for source of suppliers, competition for warehousing facilities and competition for channels of distribution. All the four 
challenges had a mean score of 3 and above, an indication that they are the major challenges the firms must address when competition with their rivals in the industry. The challenges found to have insignificant effect on the competition of horticultural export firms in Kenya were quality packaging by competitors, competition for transport challenges, threat of new entrants to the market, competitors wider branch network, imitation by competitors and poaching of qualified staff. These competition challenges have a mean score below 2.6. This indicates that the horticultural firms in Kenya should not give much attention to these challenges since they do not pose any significant threat in the industry.

\section{Conclusions and recommendations}

The study sought to establish the challenges of competition faced by horticultural firms in Nairobi County, from the study findings, the study established most of the organizations have operated in Kenya for a period between 15 - 20 years. Most of the firms under study had branches within the county with most of them having a good performance. The study also establishes that most of the firms do not operate in other countries apart from Kenya and they do not have a strategy implementation department within their organization.

The study established that the firms are being faced by various challenges including: rivalry within the industry, competition for source of suppliers, competition for warehousing facilities and competition for channels of distribution are the major challenges that the firms are facing. All the four challenges had a mean score of 3 and above, an indication that they are the major challenges the firms must address when competing with their rivals in the industry. The firms face challenges in effectively implementing their strategies due to lack of strategy implementation department.

From the study findings, it can be concluded that horticultural firms in Nairobi County, Kenya are facing various challenges of competition in the industry which could be causing problems in their performance. These challenges include rivalry within the industry, competition for source of suppliers, competition for warehousing facilities and competition for channels of distribution. The study also concludes that in order to stay in pace with the changes in the operating environment, the horticultural corporation in Nairobi county, Kenya need to develop some strategies to deal with the challenges. The researcher established that most of the firms do not have a strategy implementation department. It can therefore be concluded that the horticultural export firms should establish strategy implementation departments within their organizations to help in implementation of their operation strategies hence have a competitive advantage in their operations. It can also be concluded that the firms should enlarge their operations to other parts apart from Kenya to help them focus on other ripe markets for their produce.

The study recommends that the horticultural firms should look beyond competitive forces in the environment, by scanning the external and internal environment in search of other opportunities for revenue generation and competitive advantage. Focusing so much on competitive forces makes the organization loose on ripe opportunities that could be a great advantage for the firm.

\section{Acknowledgements}

This study benefitted from support from the management and staff of various horticultural firms who provided required data. Prof. Martin Ogutu was very instrumental in this research and his invaluable support is appreciated. A mutual friend assisted in the editing and drafting of this paper and that support is valued greatly.

[1] Chweya, J. \& L. Kimenye, (1995) Horticultural production and marketing in Kenya: project identification, pre-feasibility studies. Nairobi, Techniserve,

[2] Dolan, C. and J. Humphrey (2000) "Governance and Trade in Fresh Vegetables: impact ofUK supermarkets on the African horticulture industry" Journal of Development studies 37(2):147-176

[3] GoK (2000) Second Report on Poverty in Kenya: Volume 1- Incidence and depth of poverty. Nairobi, Government of Kenya, Ministry of Finance and Planning.

[4] John, G. \& Scholes, K. (1999) Exploring Corporate Strategy: Texts and Cases. Great Britain: Prentice Hall Europe.

[5] Miles, R. E. \& Snow, C. C. (1978) Organizational Strategy, Structure and Process. New York: McGraw Hill. Porter, M. (1990), Comp. Strategy, Free Press, New York

[6] Pearce, J.A. \& Robinson, J. B. (2005) Strategic Management: Formulation, Implementation and Control, $3^{\text {rd }}$ Edition, Richard D. Irwin 